\title{
The staining effect of cigarette smoke on different dental
}

\section{materials}

\section{Hilal EKSI OZSOY*}

Assistant Professor, Department of Prosthodontics, University of Beykent School of Dentistry, Istanbul, Turkey

Received: 04 April, 2020
Accepted: 10 April, 2020
Published: 11 April, 2020

*Corresponding author: Hilal EKSI OZSOY, School of Dentistry, Beykent University, Cumhuriyet St, Istanbul, TR 34550, Turkey, Tel: +905348792303;

E-mail: hilaleksi@gmail.com; hilalozsoy@beykent.edu.tr Keywords: Smoke; Cigarette; Color-stability

https://www.peertechz.com

Check for updates

\section{Abstract}

Among the aesthetic properties of restorative and prosthetic materials used in dentistry, color stability is an important issue. Color changes are examined using many coloring agents such as coffee, tea and mouthwash. One of these coloring agents is cigarette smoke. The rapid increase in the number of cigarette users in the world and the presence of a wide variety of dental materials have made it popular to study the impact among them. The purpose of this mini review is to evaluate the studies examining the staining effects of smoking on dental composite and denture teeth. Some studies have shown that smoking has an effect on dental materials. However, more studies are needed to examine the effect of smoking on the color stability of new dental materials.

According to the World Health Organization, every year more than 8 million people die from tobacco use. On the other hand, exposure to others' tobacco smoke contributes to heart disease, cancer and other diseases, causing an additional 1.2 million deaths annually. In addition to the harmful effect of tobacco on health, the total cost of smoking (along with health spending and productivity losses) is estimated to be 1.4 trillion USD per year and is equivalent to $1.8 \%$ of the world's annual gross domestic product. (GDP) [1].

Currently, the relationship between covid-19 pandemic which is seen all over the world, and cigarette users is examined by researchers. Liu et al. studies have shown that among patients diagnosed with COVID-19, patients with a negative history $(27.3 \%)$ were significantly higher than those with recovery or stabilization $(3.0 \%)(p=0.018)[2]$.

Apart from many studies examining the relationship between smoking and general health, there are also studies examining the effects of smoking on oral health such as gingival tissue and implant [3]. In a study of 304 young adults, Machuca, et al. [3]. Showed that periodontal health of smokers was negatively affected. In addition to the negative effects of smoking on dental and surrounding tissues, it also has a coloring effect on dental materials used for aesthetic and restorative purposes. Nevertheless, there are few studies in the literature about the effect of cigarette smoke on aesthetic restorative materials [4-6]. These few studies especially examine composite resins and denture teeth.

Dental composites are among the most commonly used restorative materials of dentistry. There are many studies on various staining agents on the continuity of aesthetic properties and color stability [7,8]. Dietschi, et al. [8]. Detected color change in composites in their studies using Erythrosine as a coloring agent. Initial studies examining the coloring effect of smoking, Raptis et al. [7], found significant changes in the color stability of composites, then this subject was enriched in other studies. Some studies have examined the painting effect of cigarettes, considering the finishing and polishing of composite materials. Alandia, et al. [5] showed that unpolished composites, except for the siloran based type, were more affected by cigarette smoke and change color. Although polished samples give better results in these studies, all composites have been shown to be affected by cigarettes and change color.

Artificial teeth enable the replacement of lost natural teeth and play a significant role in the esthetic and functional outcomes of complete dentures. Dental esthetics are related to the selection of durable and color-stable dental materials, increasing attention has been paid to improving the stain 
resistance of artificial denture teeth [9]. While some of the studies investigating the effects of smoking on dentures have evaluated acrylic teeth from different brands [4], some have examined both acrylic and porcelain dentures [4]. In these studies, it was concluded that cigarette smoke changes the color of artificial denture teeth and that porcelain denture teeth are more color-stable than acrylic resin denture teeth. Ayaz, et al. [4], found that the denture teeth with porcelain content had less color change due to cigarettes in their study using acrylic resin, high strength acrylic resin and porcelain.

Clinical implication of this study is that when long term maintenance of the matched colour for the entire length of its service life is required; the smoking habits of the patients must also be considered, while the commercially available dental materials are being chosen and patients should be advised against excessive cigarette smoking. Also, manufacturers of restorative dental materials can make necessary changes in composition and manufacturing process, to increase color stability of materials.

More research is needed to examine the color stability of dental materials used in restorative and prosthetic dentistry. In particular, research on the effects of smoking on the color change of dental ceramics and CAD-CAM materials needs to be enriched.

\section{References}

1. WHO/Health topics/Tobacco (2020). Link: https://bit.ly/3b5cVdy

2. Liu W, Tao ZW, Lei W, Ming-Li Y, Kui L, et al. (2020) Analysis of factors associated with disease outcomes in hospitalised patients with 2019 novel coronavirus disease. Chin Med J. 2020 [Epub ahead of print]. Link: https://bit.ly/3cbmV58

3. Machuca G, Rosales I, Lacalle JR, Machuca C, Bullón P (2000) Effect of Cigarette Smoking on Periodontal Status of Healthy Young Adults. J Periodontol 71: 73-78. Link: https://bit.ly/34xcXZ1

4. Ayaz EA, Altintas SH, Turgut S (2014) Effects of cigarette smoke and denture cleaners on the surface roughness and color stability of different denture teeth. J Prosthet Dent 112: 241-248. Link: https://bit.ly/2yLikrD

5. Alandia-Roman CC, Cruvinel DR, Sousa ABS, Pires-De-Souza FCP, Panzeri H (2013) Effect of cigarette smoke on color stability and surface roughness of dental composites. J Dent 41: 73-79. Link: https://bit.ly/34rmoJr

6. Patil SS, Dhakshaini MR, Kumar Gujjari A (2013) Effect of cigarette smoke on acrylic resin teeth. J Clin Diagnostic Res. 7: 2056-2059. Link: https://bit.ly/2xaKKex

7. Raptis CN, Powers JM, Fan PL, Yu R (1982) Staining of composite resins by cigarette smoke. J Oral Rehabil 9: 367-371. Link: https://bit.ly/3a0iN6q

8. Dietschi D, Campanile G, Holz J, Meyer JM (1994) Comparison of the color stability of ten new-generation composites: an in vitro study. Dent Mater 10: 353-362. Link: https://bit.ly/3b00ttz

9. Gregorius WC, Kattadiyil MT, Goodacre CJ, Roggenkamp CL, Powers JM, et al (2012) Effects of ageing and staining on color of acrylic resin denture teeth. $J$ Dent 40: 47-54. Link: https://bit.ly/2JVIsTi
Discover a bigger Impact and Visibility of your article publication with

Peertechz Publications
Highlights

* Signatory publisher of ORCID

* Signatory Publisher of DORA (San Francisco Declaration on Research Assessment)

* Articles archived in worlds' renowned service providers such as Portico, CNKI, AGRIS, TDNet, Base (Bielefeld University Library), CrossRef, Scilit, J-Gate etc.

* Journals indexed in ICMJE, SHERPA/ROMEO, Google Scholar etc.

* OAI-PMH (Open Archives Initiative Protocol for Metadata Harvesting)

* Dedicated Editorial Board for every journal

* Accurate and rapid peer-review process

* Increased citations of published articles through promotions

- Reduced timeline for article publication

Submit your articles and experience a new surge in publication services (https://www.peertechz.com/submission).

Peertechz journals wishes everlasting success in your every endeavours.

Copyright: (c) 2020 OZSOY HE. This is an open-access article distributed under the terms of the Creative Commons Attribution License, which permits unrestricted use distribution, and reproduction in any medium, provided the original author and source are credited. 